\title{
The Potency of Leptin Gene as a Selection Marker of Economic Traits for Madura Cattle: Preliminary Study
}

\author{
Tristianto Nugroho ${ }^{1}$, Tri Satya Mastuti Widi ${ }^{1}$, Dyah Maharani ${ }^{1, *}$ \\ ${ }^{1}$ Faculty of Animal Science, Universitas Gadjah Mada, Indonesia \\ *Corresponding author. Email: d.maharani@ugm.ac.id
}

\begin{abstract}
The Leptin gene, also known as 'obese', was an important regulator of growth traits which is the principal economic value of beef cattle. This paper aimed to investigate the potency of the Leptin gene as a selection marker of economic traits for Madura cattle. This study was performed by literature review from published studies. First, publications were collected to obtain a Leptin genes study on Madura cattle and Indonesian Cattle. Next, association study publications were collected to obtain Leptin gene polymorphism and its effect on the economic traits of various cattle. The selected economic traits were growth, carcass, milk, and reproduction. In total, 26 papers were used in this study. As a results, we found Leptin gene studies on nine Indonesian local cattle, including Madura, Kebumen Ongole Grade, Ongole Grade, Sumba Ongole, Bali, Pasundan, Bali Cross, Pesisir and Ciamis Local Cattle. However, most of this study is limited to polymorphism identification. Exon 2, Intron 2, and Exon 3 of the Leptin gene polymorphism were associated with four selected economic traits on several loci. However, Leptin gene SNP g.1180C >T (also referred to as R25C, Arg25Cys, 1047C > T, C305T, R4C, C73T, and LepKpn2I) in exon 2 was known to had association with growth, carcass, milk, and reproduction trait. It was concluded that SNP g.1180C $>\mathrm{T}$ had the potency to be used as a selection marker of economic traits for Madura cattle. Following marker selection, an association study on Madura Cattle was further to validate this result.
\end{abstract}

Keywords: Leptin Gene, Selection Marker, Madura Cattle, Economic Trait

\section{INTRODUCTION}

Madura cattle were meat-type cattle that originated from Madura Island, Indonesia. They were registered as local Indonesian cattle by the Ministry of Agriculture Republic of Indonesia (3735/Kpts/HK.040/11/2010) [1]. The origin of these cattle was divided into two versions. The first version explains that Madura cattle possibly derived from a crossbreed between Bali Cattle and/or the wild Banteng (Bos (bibos) banteng), Bos Indicus, and Bos Taurus [2]. It had supported by the finding of Taurine ZFY and SRY gene segments [3]. However, the famous version explains that Madura cattle are a crossbreed between Wild Banteng (Bos javanicus) and Zebu (Bos indicus) developed 1500 years ago [3,4].

Madurese culture had a heavy impact on the development of Madura cattle. Karapan Sapi (paired bull race) developed in all areas of Madura Isle starting around the $12-13^{\text {th }}$ century. Madura cattle had been selected for light and small body size to support for run faster in the event. In the long term, it brought adverse effects on the genetic quality of Madura cattle [5]. Based on that condition, in the northern part of the island, farmers started another cultural event called Sonok (cow body conformation contest) in the '60s to stimulate farmers to improve their cattle performance. Nowadays, this traditional selection produces high cattle performance. This cultural event, however, generates three cattle classes called Sonok (selected for the contest), Taccek/Pajengan (Sonok candidate), and conventional (unselected for the contest), which had different characteristics [6]. 


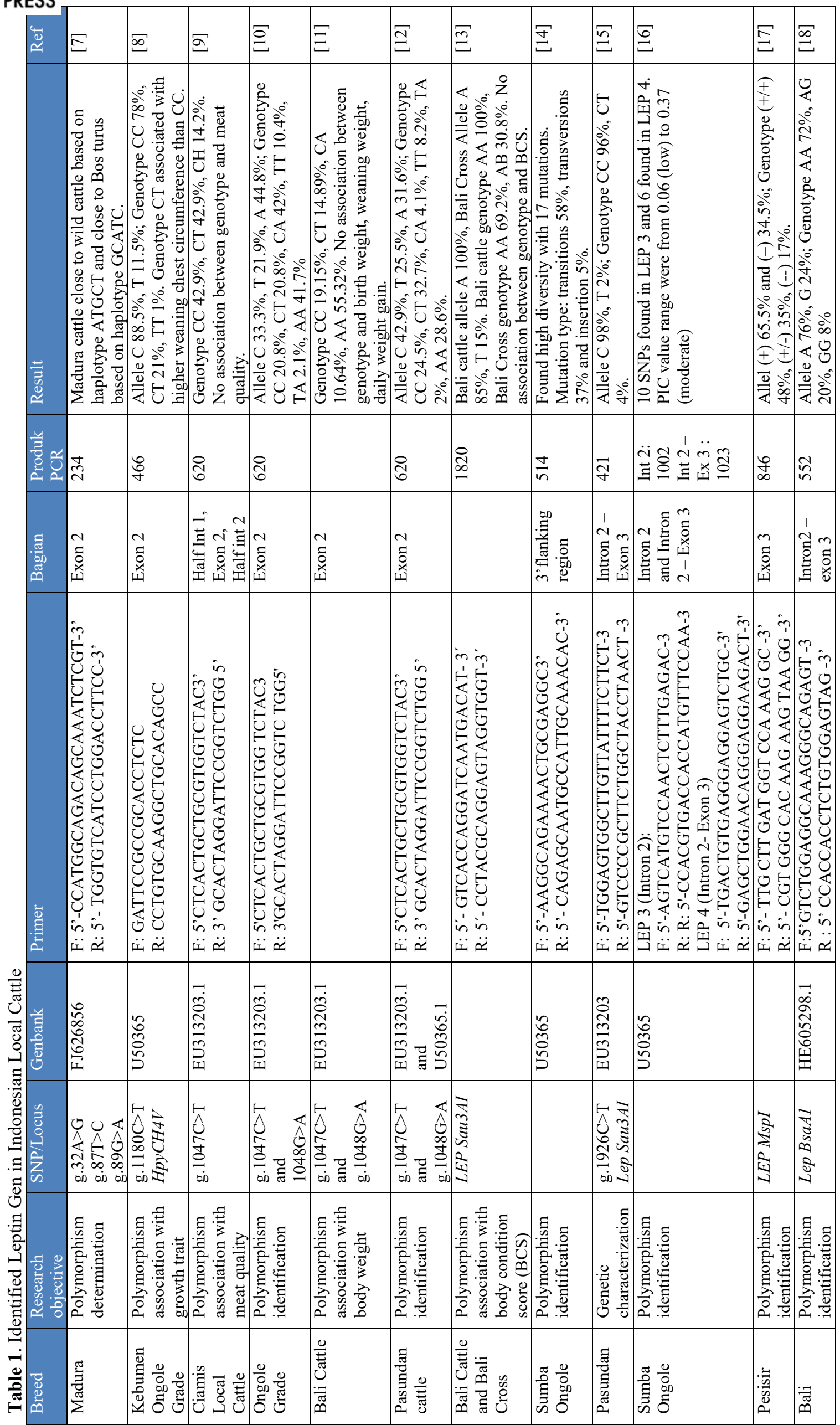


Based on the cultural event involving Madura cattle, it had proven that selection over the generation could change the character of the cattle. Selection aimed to produce livestock to reach the breeding objective or breeding goal, thus allowing for different economic values. Unfortunately, the traditional selection is no longer efficient, time-consuming, and inaccurate. Currently, a faster selection tool can be done early and accurately, called Marker-Assisted Selection (MAS). This method could be used for both quantitative and qualitative selection [19]. In the case of Madura cattle for the cultural event, which was selected based on body conformation, quantitative selection could make using associated genes. However, it should be noted that one gene can code for many traits. Many genes can code one trait; thus, careful consideration had needed. [20].

The Leptin gene was known to regulate adipose tissue and body weight by inhibiting feed intake and energy expenditure stimulation. The gene regulation was necessary for beef cattle, which aimed to produce high productivity. The Leptin gene in cattle had located on chromosome 4 (BTA4q32), has a length of 16,735 base pairs (bp) and consists of 2 introns and three exons as well [21]. The first intron is more than $8 \mathrm{~kb}$ and the second intron has a length of $1.6 \mathrm{~kb}$ [22]. Leptin consists of 167 amino acids and had a molecular weight of $16 \mathrm{kDa}$ [23]. The Leptin gene functions to produce the hormone Leptin, synthesized from adipose tissue (fat). The hormone Leptin then plays an essential role in controlling body weight, feed consumption, and energy balance [24]. Thus, this study aimed to investigate the potency of the Leptin gene as a selection marker of economic traits for Madura cattle.

\section{METHODS}

This study had performed a literature review from published studies. First, publications were collected to obtain a list of Leptin genes in Madura cattle. Because of the limited study found, we then collected Leptin gene study publications in various Indonesian cattle. We reviewed the references section for each manuscript to ensure that we included the highest number of relevant studies. Only electronic publications written in English and Indonesian had used in this study. Next, publications were collected to obtain the association of Leptin gene polymorphism to the economic traits in various cattle. The selected economic traits were body conformation, carcass, milk, and reproduction. Body conformation consisted of body weight and body measurement. Even though Madura cattle were meat-type cattle, the milk production trait had included because it relates to mothering abilities and the environmental dam effect. In total, 26 papers had used in this study.

\section{RESULTS AND DISCUSSION}

\subsection{Leptin Gene Studies in Indonesia}

In Indonesia, studies on the Leptin gene in local cattle were limited. Several studies of the Leptin gene in cattle breeds in Indonesia include Madura cattle, Kebumen Ongole Grade, Ciamis Local Cattle, Ongole Grade, Bali Cattle, Pasundan Cattle, Bali Cross, Sumba Ongole, and Pesisir Cattle (Table 1). Most studies use GenBank accession numbers U50365 and EU313203.1. The part that had often use was exon 2. The length of the PCR product fragment taken is between 234 to $1820 \mathrm{bp}$. Several mutations in the exon two portion of the Leptin gene cause changes in certain amino acids that can affect livestock productivity [25-27].

However, so far, the research has been limited to identifying polymorphisms. Therefore, it cannot be used for selection because it only knows the diversity. In order used as a selection tool, it was necessary to know whether or not there was an association of polymorphism with phenotypic traits. Some researchers have associated polymorphism with phenotypic traits, although results vary. Fathoni et al [28] had stated that the Leptin gene polymorphism g. 1080C $>\mathrm{T}$ was associated with weaning chest circumference in Kebumen Ongole Grade cattle. Meanwhile, other researchers stated no association between genotype and meat quality, birth weight, weaning weight, daily weight gain, and body condition score. $[9,12,13]$.

\subsection{Leptin Gene Studies on Various Cattle}

We found several SNPs associated with economic traits. SNPs had located in Exon 2, Intron 2, and Exon 3. Leptin gene association studies on various cattle showed in Table 2. Exon 1 of the Leptin gene had included in the promoter region with a small number of bases, so it assumed that it does not affect the association [29].

Exon 2 Leptin gene studies were found mostly in SNP $1180 \mathrm{C}>\mathrm{T}$ and were associated with four selected economic traits. The CT genotype had a weaning chest circumference, $3.5 \%$ FCM, higher milk fat, and true milk protein than the CC genotype. The CC genotype had a higher backfat thickness in Korean and Hanwoo cattle but lower in crossbred cattle than the TT genotype. The CC genotype produced a higher Marbling score, yield grade, lean meat yield, longissimus muscle area than the TT genotype in Korean cattle, crossbreed steer, and Hanwoo cattle. In terms of reproduction, the CC genotype in Holstein cattle produced Estrous cyclic at 49 \pm 3 DIM, which was higher than TT. The base mutation of Cytosine to Tymin at position 1180 converts the amino acid Arginine to Cysteine. SNP $1180 \mathrm{C}>\mathrm{T}$ has several other names including R25C, Arg25Cys, $1047 \mathrm{C}>\mathrm{T}$, C305T, R4C, C73T and LepKpn2I [11,25,30-32]. This amino acid change had thought to be a causative mutation 
that causes changes in the physiological work of the hormone Leptin in energy metabolism. The conversion of Arginine to Cysteine causes the binding capacity and function to return to the wild type, and this shows the importance of Cysteine Sulfihydryl [32]. Furthermore, this base change had proposed as a nonconserved substitution imparting a potential partial loss of biological function that is associated with fatter carcasses and higher Leptin mRNA levels [31,33]. Another hypothesis was that mutation changes the tertiary conformation of the Leptin protein by adding unpaired cysteine to its structure, thereby changing the affinity of the hormone for its receptor as evidenced by changes in Leptin concentrations. [34].

Table 2. Association of Leptin gen with Economic trait on various cattle

\begin{tabular}{|c|c|c|c|c|c|}
\hline SNP/Locus & Trait & Genotype & $\begin{array}{c}\text { Best } \\
\text { Genotype } \\
\text { Frequency }\end{array}$ & Breed & Ref \\
\hline \multicolumn{6}{|l|}{ Exon 2} \\
\hline $1180 \mathrm{C}>\mathrm{T}$ & Weaning chest circumference & $\mathrm{CT} \uparrow, \mathrm{CC} \downarrow$ & $21 \%$ & Kebumen Ongole Grade & {$[8]$} \\
\hline $1180 \mathrm{C}>\mathrm{T}$ & Body weight & $\mathrm{CT} \uparrow, \mathrm{TT} \downarrow$ & $47.7 \%$ & Crosbred Cattle & [25] \\
\hline $1180 \mathrm{C}>\mathrm{T}$ & Backfat thickness & $\mathrm{TT} \uparrow, \mathrm{CC} \downarrow$ & $22.6 \%$ & Crosbred Cattle & {$[25]$} \\
\hline $1180 \mathrm{C}>\mathrm{T}$ & Backfat thickness & $\mathrm{CC} \uparrow, \mathrm{TT} \downarrow$ & $29.2 \%$ & Korean Cattle & {$[35]$} \\
\hline $1180 \mathrm{C}>\mathrm{T}$ & Marbling score & $\mathrm{CC} \uparrow, \mathrm{TT} \downarrow$ & $29.2 \%$ & Korean Cattle & [35] \\
\hline $1180 \mathrm{C}>\mathrm{T}$ & Gain in backfat thickness & $\mathrm{TT} \uparrow, \mathrm{CC} \downarrow$ & $26.38 \%$ & Crossbreed steer & [33] \\
\hline $1180 \mathrm{C}>\mathrm{T}$ & Ultrasound backfat thickness & $\mathrm{TT} \uparrow, \mathrm{CC} \downarrow$ & $26.38 \%$ & Crossbreed steer & [33] \\
\hline $1180 \mathrm{C}>\mathrm{T}$ & Grade fat (backfat) & $\mathrm{TT} \uparrow, \mathrm{CC} \downarrow$ & $26.38 \%$ & Crossbreed steer & [33] \\
\hline $1180 \mathrm{C}>\mathrm{T}$ & Yield grade & $\mathrm{CC} \uparrow, \mathrm{TT} \downarrow$ & $26.38 \%$ & Crossbreed steer & {$[33]$} \\
\hline $1180 \mathrm{C}>\mathrm{T}$ & Lean meat yield & $\mathrm{CC} \uparrow, \mathrm{TT} \downarrow$ & $22.2 \%$ & Crossbreed steer & {$[33]$} \\
\hline $1180 \mathrm{C}>\mathrm{T}$ & Back fat thickness & $\mathrm{CC} \uparrow, \mathrm{TT} \downarrow$ & $26.2 \%$ & Hanwoo Cattle & {$[36]$} \\
\hline $1180 \mathrm{C}>\mathrm{T}$ & Longisimus muscle area & $\mathrm{CC} \uparrow, \mathrm{TT} \downarrow$ & $26.2 \%$ & Hanwoo Cattle & {$[36]$} \\
\hline $1180 \mathrm{C}>\mathrm{T}$ & Estrous cyclic at $49 \pm 3$ DIM & $\mathrm{CC} \uparrow, \mathrm{TT} \downarrow$ & $34.6 \%$ & Holstein Cows & [34] \\
\hline $1180 \mathrm{C}>\mathrm{T}$ & $3.5 \%$ FCM & $\mathrm{CT} \uparrow, \mathrm{CC} \downarrow$ & $48.2 \%$ & Holstein Cows & [31] \\
\hline $1180 \mathrm{C}>\mathrm{T}$ & Milk fat & $\mathrm{CT} \uparrow, \mathrm{CC} \downarrow$ & $48.2 \%$ & Holstein Cows & {$[31]$} \\
\hline $1180 \mathrm{C}>\mathrm{T}$ & Milk true protein & $\mathrm{CT} \uparrow, \mathrm{CC} \downarrow$ & $48.2 \%$ & Holstein Cows & {$[31]$} \\
\hline \multicolumn{6}{|l|}{ Intron 2} \\
\hline BstMB1 & Weight at 9 month & $\mathrm{AB} \uparrow, \mathrm{AA} \downarrow$ & $22 \%$ & Sistani Cows & [37] \\
\hline BstMB1 & Weight at 12 month & $\mathrm{AB} \uparrow, \mathrm{AA} \downarrow$ & $22 \%$ & Sistani Cows & [37] \\
\hline BstMB1 & Days open & $\mathrm{AA} \uparrow, \mathrm{AB} \downarrow$ & $64 \%$ & Brown Swiss & [37] \\
\hline BstMB1 & Age at conception & $\mathrm{AB} \uparrow, \mathrm{AA} \downarrow$ & $22 \%$ & Sistani Cows & {$[37]$} \\
\hline BstMB1 & 1 month lactation & $\mathrm{AB} \uparrow, \mathrm{AA} \downarrow$ & $35 \%$ & Brown Swiss & [37] \\
\hline BstMB1 & 2 month lactation & $\mathrm{AB} \uparrow, \mathrm{AA} \downarrow$ & $35 \%$ & Brown Swiss & [37] \\
\hline BstMB1 & 3 month lactation & $\mathrm{AB} \uparrow, \mathrm{AA} \downarrow$ & $35 \%$ & Brown Swiss & [37] \\
\hline BstMB1 & 4 month lactation & $\mathrm{AB} \uparrow, \mathrm{AA} \downarrow$ & $35 \%$ & Brown Swiss & [37] \\
\hline BstMB1 & 60 days milk production & $\mathrm{AB} \uparrow, \mathrm{AA} \downarrow$ & $35 \%$ & Brown Swiss & [37] \\
\hline BstMB1 & 100 days milk production & $\mathrm{AB} \uparrow, \mathrm{AA} \downarrow$ & $35 \%$ & Brown Swiss & [37] \\
\hline BstMB1 & Milk days & $\mathrm{AA} \uparrow, \mathrm{AB} \downarrow$ & $64 \%$ & Brown Swiss & {$[37]$} \\
\hline LEP/Sau3AI & Carcass weight & $\mathrm{AA} \uparrow, \mathrm{AC} \downarrow$ & $69.5 \%$ & Friesian Bulls & [38] \\
\hline LEP/Sau3AI & Calving interval & $+-\uparrow,--\downarrow$ & $12.7 \%$ & Angus-Nelore Cross & [39] \\
\hline LEP/Sau3AI & Age at first calving & $\mathrm{AB} \uparrow, \mathrm{AA} \downarrow$ & $32.6 \%$ & Slovak Spotted and Pinzgau & [40] \\
\hline LEP/Sau3AI & Milk yield & $\mathrm{AA} \uparrow, \mathrm{BB} \downarrow$ & $63.7 \%$ & Slovak Spotted and Pinzgau & [40] \\
\hline LEP/Sau3AI & Protein yield & $\mathrm{AA} \uparrow, \mathrm{BB} \downarrow$ & $63.7 \%$ & Slovak Spotted and Pinzgau & {$[40]$} \\
\hline LEP/Sau3AI & Fat yield & $\mathrm{AA} \uparrow, \mathrm{BB} \downarrow$ & $63.7 \%$ & Slovak Spotted and Pinzgau & [40] \\
\hline \multicolumn{6}{|l|}{ Exon 3} \\
\hline $\mathrm{SSCP}^{1}$ & Birth weight & $\mathrm{BB} \uparrow, \mathrm{AA} \downarrow$ & $29.3 \%$ & Nanyang Cattle & [41] \\
\hline $\mathrm{SSCP}^{1}$ & $6 \mathrm{~m}$ withers height & $\mathrm{BB} \uparrow, \mathrm{AA} \downarrow$ & $29.3 \%$ & Nanyang Cattle & [41] \\
\hline $\mathrm{SSCP}^{1}$ & $6 \mathrm{~m}$ body length & $\mathrm{BB} \uparrow, \mathrm{AA} \downarrow$ & $29.3 \%$ & Nanyang Cattle & [41] \\
\hline $\mathrm{SSCP}^{1}$ & $6 \mathrm{~m}$ heart girth & $\mathrm{BB} \uparrow, \mathrm{AA} \downarrow$ & $29.3 \%$ & Nanyang Cattle & [41] \\
\hline $\mathrm{SSCP}^{1}$ & $6 \mathrm{~m}$ body weight & $\mathrm{BB} \uparrow, \mathrm{AA} \downarrow$ & $29.3 \%$ & Nanyang Cattle & [41] \\
\hline $\mathrm{SSCP}^{1}$ & $6 \mathrm{~m}$ average day gain & $\mathrm{BB} \uparrow, \mathrm{AB} \downarrow$ & $29.3 \%$ & Nanyang Cattle & [41] \\
\hline $\mathrm{SSCP}^{1}$ & 2y Withers height & $\mathrm{BB} \uparrow, \mathrm{AB}$ & $29.3 \%$ & Nanyang Cattle & [41] \\
\hline $\mathrm{SSCP}^{1}$ & $2 \mathrm{y}$ Body length & $\mathrm{BB} \uparrow, \mathrm{AB}$ & $29.3 \%$ & Nanyang Cattle & [41] \\
\hline $\mathrm{SSCP}^{1}$ & $2 \mathrm{y}$ Heart girth & $\mathrm{BB} \uparrow, \mathrm{AB}$ & $29.3 \%$ & Nanyang Cattle & [41] \\
\hline $\mathrm{SSCP}^{1}$ & 2y Body weight & $\mathrm{BB} \uparrow, \mathrm{AB}$ & $29.3 \%$ & Nanyang Cattle & [41] \\
\hline $\mathrm{SSCP}^{1}$ & 2y Average day gain & $\mathrm{BB} \uparrow, \mathrm{AB}$ & $29.3 \%$ & Nanyang Cattle & [41] \\
\hline A80V & Non-return rate in cows & $\mathrm{TT} \uparrow, \mathrm{CC} \downarrow$ & $7.1 \%$ & Polish Holstein-Friesian bulls & [30] \\
\hline$L E P / M s p I$ & Marbling score & $\mathrm{AA} \uparrow, \mathrm{BB} \downarrow$ & $29.4 \%$ & Hanwoo Cattle & [36] \\
\hline rs29004509 $(\mathrm{C}>\mathrm{T})$ & Milk yield & $\mathrm{CT} \uparrow, \mathrm{CC} \downarrow$ & $20 \%$ & Karan Fries & {$[42]$} \\
\hline
\end{tabular}

Note: $\mathrm{SSCP}^{1}=66$ th bp position $\mathrm{G} \rightarrow \mathrm{T}$ transversion, 67 th bp position $\mathrm{A} \rightarrow \mathrm{C}$ transversion and 299th bp position $\mathrm{G} \rightarrow \mathrm{T}$ transversion 
Leptin gene mutations in intron two were associated with growth, carcass, reproduction, and milk traits. We found two positions based on published studies, namely $L E P / B$ stMB 1 and $L E P / S a u 3 A I$. Sistani cattle with genotype $\mathrm{AB}$ in $L E P / B s t M B 1$ had higher body weight and age at conception than genotype AA. Meanwhile, Swiss Brown Cows with genotype AB in $L E P / B s t M B 1$ had higher milk production and shorter open days but had lower milk days than genotype AA. Genotype AA in LEP/Sau3AI Slovak Spotted and Pinzgau cattle had known to produce higher milk production and quality than genotype $\mathrm{AB}$.

Meanwhile, genotype AA had a higher carcass weight than AC, and genotype (+-) had a higher calving interval than (--). Introns were known as non-coding regions because they remove before a protein was made. However, some non-coding DNA still had an essential role in regulating gene expression, that was to changes in introns, possibly affecting changes to the coding region (REF) portion. Allele $\mathrm{B}$ in $L E P / B s t M B 1$ is the favorable allele in selected economic traits. However, this allele is recessive. In contrast to these mutations, the association of the $L E P / S a u 3 A I$ gene did not form a uniform pattern. SNP LEP/Sau $3 A I$ are change of cytosine to thymine and results in amino acid change arginine by cysteine at position 2059 of the protein chain [40].

We did not find much research done on the Exon 3 Leptin gene. However, based on published research, it was found that 4 SNPs were associated with economic traits. The SNPs found were A80V, LEP/Msp I, and rs29004509 (C>T). In addition, mutations detected with SSCP were also found, with mutations at position 66th bp position $\mathrm{G} \rightarrow \mathrm{T}$ transversion, 67th bp position $\mathrm{A} \rightarrow \mathrm{C}$ transversion, and 299th bp position $\mathrm{G} \rightarrow \mathrm{T}$ transversion. Cows with the BB genotype in the SSCP study had a growth trait from birth to 2 years of age higher than the $\mathrm{AA}$ and $\mathrm{AB}$ genotypes. From birth to 6 months, genotype $\mathrm{AB}$ had also higher than $\mathrm{AA}$, but because the average daily gain is lower, at the age of 2 years, genotype $A B$ had a lower growth trait than AA. Although this study showed good results, further research is still needed to find a more specific effect on one of the mutation positions [41]. On the other hand, SNP A80V is a causative mutation that affects the non-return rate compared to other SNPs. Mutations at this position include conservative substitutions because alanine and valine are in the same non-polar amino acid group [30].

\subsection{Potency of Leptin Gene as Selection Marker of Economic Trait for Madura Cattle}

Madura cattle in the Madura island were kept based on the breeding goals of each farmer. Not only kept as beef cattle to produce meat, but Madura cattle had also kept for body conformation contests and racing. The main concern of breeders was body size and other qualitative traits. However, this selection had been shown to produce differences in body size characteristics. Based on this fact, it concluded that the selection of Madura cattle could run effectively. If Madura cattle had only improved for beef cattle whose economic value had to calculate from growth, carcass, milk, and reproduction traits, it would be better to become marker-assisted selection.

Sonok, Taccek, Karapan, and conventional cattle had different body sizes. It was necessary to measure their genetic profile through molecular analysis. Based on this profile, the differences between each cattle. If genetic profiles showed different profiles between types of cattle, this genetic profile could be used as the basis for selecting parent stock that produces the next generation. On the other hand, if the genetic profile between cattle is the same, basically every cow has the same genetic potential. Then, it can be a sign that the phenotypic differences are not genetic but were affected by non-genetic factors, such as livestock management.

In this study, it had found that leptin gene polymorphisms at various locations affected economic traits. However, the leptin gene polymorphism location that affects the four selected economic traits only SNP g.1180 C > T (R25C, Arg25Cys, 1047C > T C305T, R4C, C73T, and LepKpn2I), which had located in exon 2. Therefore, this SNP location is the most potential location to be used as the basis for selecting economic traits. The research results summarized in this paper indicate that the best genotype for each trait is different and depends on the breed of cattle. For example, the gain in backfat thickness trait in crossbreed cattle is TT genotype, but the best backfat thickness trait in Hanwoo cattle is CC. Based on this, it is necessary to conduct further research on Madura cattle to determine the best genotype for each trait.

Application of the use of the leptin gene in Madura cattle could be conducted by identifying the genotype of the leptin gene in a livestock population. The cattle population to be selected should meet the standards of good farming practices so that genetic potential can be expressed. The leptin gene genotype data obtained were then statistically associated with livestock productivity data [43].

\section{CONCLUSION}

The result concluded that Leptin SNP g.1180C $>\mathrm{T}$ (R25C, Arg25Cys, 1047C > T, C305T, R4C, C73T, and LepKpn2I) has the potency to be used as a selection marker of economic traits for Madura cattle. Following marker selection, an association study on Madura Cattle is further to validate this result.

\section{AUTHORS' CONTRIBUTIONS}

TN: Conception, conducted the literature review, data acquisition, data analysis and interpretation, manuscript drafting, and revision. TSMW: Conception and 
manuscript correction. DM: Conception and manuscript correction.

\section{ACKNOWLEDGMENTS}

This research was a preliminary study of a project entitled "Analysis of Madura Cattle Breeding System in Sonok Area on Madura Island." The project was funded by Faculty of Animal Science, Universitas Gadjah Mada, under the grant scheme Hibah Kompetisi Pascasarjana 2020. Tri Satya Mastuti Widi Ph.D. coordinated the grant

\section{REFERENCES}

[1] Menteri Pertanian 2010 Keputusan Menteri Pertanian Nomor 3735/Kpts/HK.040/11/2010 Tentang Penetapan Rumpun Sapi Madura

[2] Payne W and Rollinson D 1976 Madura cattle Z. Timuchtg. Zuchtgsbiol. 93 89-100

[3] Mohamad K, Olsson M, Tol H T A Van, Mikko S, Vlamings B H, Rodrı H, Colenbrander B and Lenstra J A 2009 On the Origin of Indonesian Cattle PLoS One 4 e5490

[4] Sutarno and Setyawan A D 2015 Review : Genetic diversity of local and exotic cattle and their crossbreeding impact on the quality of Indonesian cattle Biodiversitas 16 327-54

[5] Widyas N, Prastowo S, Haryanto R, Nugroho T and Widi T S M 2019 Madura cattle stratification as a signature of traditional selection and diverse production systems IOP Conf. Ser. Earth Environ. Sci. 387012120

[6] Nugroho T, Maharani D and Widi T S M 2019 Identifying the stakeholders and sustainability indicators for sonok breeding system IOP Conf. Ser. Earth Environ. Sci. 387012133

[7] Kamaliah 2012 Polimorfisme Gen Leptin Dan Gen Miostatin pada Sapi Potong Aceh dan Madura (Institut Pertanian Bogor)

[8] Fathoni A, Maharani D, Aji R N, Choiri R and Sumadi S 2019 Polymorphism of the SNP g. 1180 $\mathrm{C}>\mathrm{T}$ in leptin gene and its association with growth traits and linear body measurement in Kebumen Ongole Grade cattle J. Indones. Trop. Anim. Agric. 44 125-34

[9] Hilmia N, Noor R R, Sumantri C, Priyanto R and Gurnadi E 2015 Hubungan keragaman gen Leptin dengan kualitas fisik daging sapi lokal di Ciamis $J$. Ilmu Ternak 15 53-60

[10] Hilmia N, Rahmat D and Dudi D 2018 Leptin gene polymorphism of Ongole Grade cattle based on single nucleotide polymorphism J. Indones. Trop. Anim. Agric. 43 309-14

[11] Hilmia N, Rahmad D and Dudi 2019 Association of Mutation on Exon 2 Leptin Gene With Birth Weight, Average Daily Gain And Weaning Weight of Baliness Cattle Ziraa'ah 44 91-7

[12] Hilmia N, Rahmat D, Dudi and Hadi D N 2019 Single Nucleotide Polymorphism on Exon 2 Leptin Gene of Pasundan Cattle IOP Conf. Ser. Earth Environ. Sci. 334

[13] Mappanganro R, Rahardja D P and Sonjaya H 2014 Hubungan Antara Gen Leptin Dengan Skor Kondisi Tubuh Induk Sapi Bali Dan Persilangannya J. Sains Teknol. Desember 2014, Vol.14 No.3 232 - 24014 232-40

[14] Putra W P B, Agung P P and Wulandari A S 2017 Profile of 3'Flanking Region of Leptin Gene in Sumba Ongole (So) Cattle Bul. Peternak. 41371

[15] Putra W P B, Anwar S, Said S, Indarto R A A and Wulandari P 2019 Genetic Characterization of Thyroglobulin and Leptin Genes in Pasundan Cattle at West Java Bul. Peternak. 43 1-7

[16] Putra W P B and Agung P P 2020 Novel Single Nucleo $\lambda \lambda$ de Polymorphisms (SNPs) in Intron 2 and Exon 3 Regions of Lep $\lambda \lambda n$ Gene in Sumba Ongole

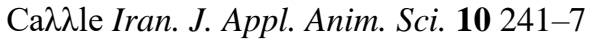

[17] Sari J M 2019 Keragaman genetik Gen Leptin (LEP-MspI) Ekson 3 Awal pada Sapi Pesisir dengan Menggunakan Metode PCR-RFLP (Universitas Andalas)

[18] Syarifulaya N, Made S and Maskur 2015 Identifikasi Keragaman Gen Leptin pada Sapi Bali dan Kambing Kacang J. Ilmu dan Teknol. Peternak. Indones. 147-54

[19] Wakchaure R, Ganguly S, Praveen P K, Kumar A, Sharma S and Mahajan T 2015 Marker Assisted Selection (MAS) in Animal Breeding: A Review $J$. Drug Metab. Toxicol. 06 1000e127

[20] Zepeda Batista J L, Carrillo Díaz M I and Saavedra Jiménez L A 2018 Sources of bias in genetic association studies in cattle: A review Rev. Colomb. Ciencias Pecu. 31 256-66

[21] Pfister-Genkow M, Hayes H, Eggen A and Bishop M D 1995 Chromosomal Localization of the bovine obesity $(O B S)$ gene

[22] Liefers S C, Te Pas M F W, Veerkamp R F and Van Der Lende T 2002 Associations between leptin gene polymorphisms and production, live weight, energy balance, feed intake, and fertility in Holstein heifers J. Dairy Sci. 85 1633-8 
[23] Taniguchi Y, Itoh T, Yamada T and Sasaki Y 2002 Genomic Structure and Promoter Analysis of the Bovine Leptin Gene Biochem. Biophys. Res. Commun. 53 131-5

[24] Fruhbeck G, Jebb S A and Prentice A M 1998 Leptin : physiology and pathophysiology 399-419

[25] Woronuk G N, Marquess F L, James S T, Palmer J, Berryere T, Deobald H, Howie S and Kononoff P J 2012 Association of leptin genotypes with beef cattle characteristics Anim. Genet. 02320

[26] Kawaguchi F, Okura K, Oyama K, Mannen H and Sasazaki S 2016 Identi fi cation of leptin gene polymorphisms associated with carcass traits and fatty acid composition in Japanese Black cattle Anim. Sci. J. 12672

[27] Kononoff P J, Defoor P J and Engler M J 2017 Impacts of a leptin SNP on growth performance and carcass characters in finishing steers studied over time J. Anim. Sci. 95 194-200

[28] Fathoni A, Maharani D, Aji R N, Choiri R and Sumadi S 2019 Polymorphism of the SNP g. 1180 $\mathrm{C}>\mathrm{T}$ in leptin gene and its association with growth traits and linear body measurement in Kebumen Ongole Grade cattle J. Indones. Trop. Anim. Agric. 44 125-34

[29] Haruna I L, Hadebe S A, Oladosu O J, Mahmoud G, Zhou H and Hickford J G H 2020 Identification of novel nucleotide sequence variations in an extended region of the bovine leptin gene (LEP) across a variety of cattle breeds from New Zealand and Nigeria Arch. Anim. Breed. 63 241-8

[30] Komisarek J 2010 Impact of LEP and LEPR gene polymorphisms on functional traits in Polish Holstein-Friesian cattle Anim. Sci. Pap. Reports 28 133-41

[31] Chebel R C, Susca F and Santos J E P 2008 Leptin Genotype Is Associated with Lactation Performance and Health of Holstein Cows J. Dairy Sci. 91 2893-900

[32] Hilmia N, Wiyatna M F, Rahmad D, Dudi, Rosidin R A and Hadi D N 2021 The Effect of Mutation on Leptin Gene to Backfat Thickness And Body Condition Score In Ongole Grade Cattle Ziraa'ah 46 112-8

[33] Nkrumah J D, Li C, Basarab J B, Guercio S, Meng Y, Murdoch B, Hansen C and Moore S S 2004 Association of a single nucleotide polymorphism in the bovine leptin gene with feed intake, feed efficiency, growth, feeding behaviour, carcass quality and body composition Can. J. Anim. Sci. 84 211-9
[34] Chebel R C and Santos J E P 2011 Association between leptin single nucleotide polymorphism and reproductive performance of lactating Holstein cows Anim. Reprod. Sci. 127 126-34

[35] Shin S C and Chung E R 2007 Association of SNP Marker in the Leptin Gene with Carcass and Meat Quality Traits in Korean Cattle Asian Australas. J. Anim. Sci. 20 1-6

[36] Kong H S, Oh J D, Lee S G, Hong Y S, Song W I, Lee S J, Kim H C, Yoo B H, Lee H K and Jeon G J 2006 Association of polymorphisms in the bovine leptin gene with ultrasound measurements for improving in Korean cattle Asian-Australasian J. Anim. Sci. 19 1691-5

[37] Nobari K, Ghazanfari S, Nassiry M R, Tahmoorespur M and Jorjani E 2010 Relationship Between Leptin Gene Polymorphism with Economical Traits in Iranian Sistani and Brown Swiss Cows J. Anim. Vet. Adv. 9 2807-10

[38] Oprzadek J, Flisikowski K, Zwierzchowski L and Dymnicki E 2003 Polymorphisms at loci of leptin (LEP), Pit1 and STAT5A and their association with growth, feed conversion and carcass quality in Black-and-White bulls Anim. Sci. Pap. Reports 21 135-45

[39] Almeida S E M, Almeida E A, Moraes J C F and Weimer T A 2003 Molecular markers in the LEP gene and reproductive performance of beef cattle $J$. Anim. Breed. Genet. 120 106-13

[40] Trakovická A, Moravčíková N and Kasarda R 2013 Genetic polymorphisms of leptin and leptin receptor genes in relation with production and reproduction traits in cattle * Acta Biochim. Pol. 60 783-7

[41] Yang D, Chen H, Wang X, Tian Z, Tang L, Zhang Z, Lei C, Zhang L and Wang Y 2007 Association of Polymorphisms of Leptin Gene with Body Weight and Body Sizes Indexes in Chinese Indigenous Cattle J. Genet. genomics 34 400-5

[42] Dar M R, Singh M, Thakur S and Verma A 2021 Exploring the relationship between polymorphisms of leptin and IGF - 1 genes with milk yield in indicine and taurine crossbred cows Trop. Anim. Health Prod. 53413

[43] Putra W P B and Indriastuti R 2017 Gen Leptin sebagai Gen Potensial untuk Seleksi Molekuler pada Sapi di Indonesia ( Leptin Gene as Potential Gene for Molecular Selection on Cattle in Indonesia ) Wartazoa 27 105-16 